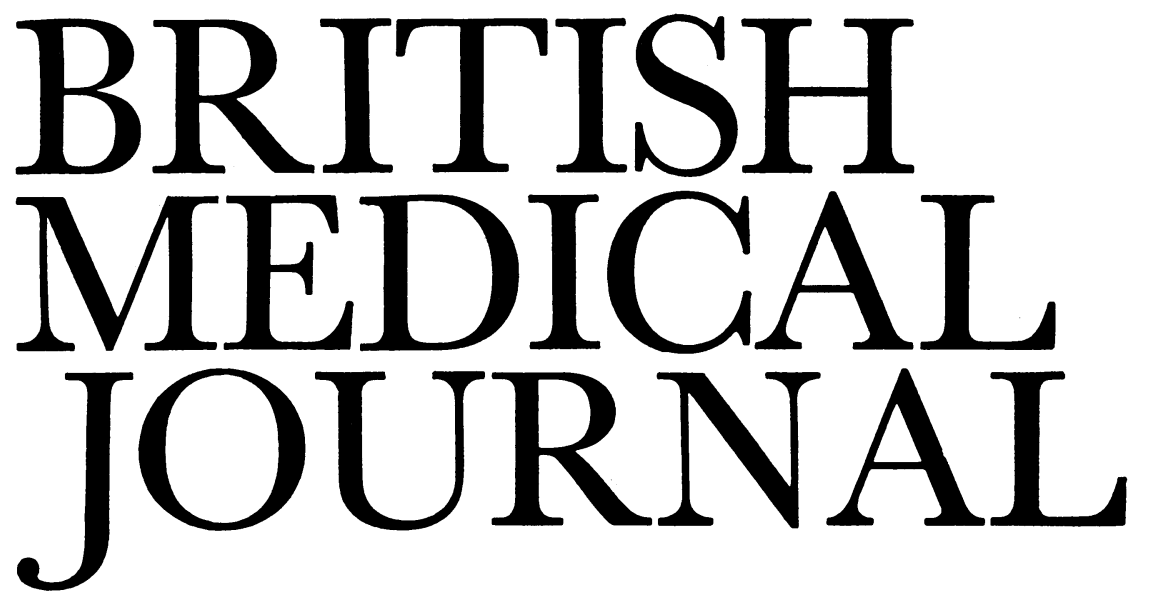

\title{
Carbon monoxide poisoning
}

Carbon monoxide is a tasteless, odourless, colourless, and non-irritating gas produced by incomplete combustion of organic materials. It is also produced in man during the catabolism of haemoglobin. The normal endogenous production of carbon monoxide is sufficient to saturate $0 \cdot 4-0 \cdot 7 \%$ of the body's haemoglobin - that is, $0 \cdot 4-0 \cdot 7 \%$ carboxyhaemoglobinaemia - at rest, ${ }^{1}$ but a national survey in North America found $1-2 \%$ carboxyhaemoglobinaemia in urban nonsmokers as a result of environmental exposure and 5-6\% in smokers (cigarette smoke contains about $4 \%$ carbon monoxide). ${ }^{2}$

Although mortality from carbon monoxide poisoning has fallen since natural gas was substituted for coal gas, about 1000 people die annually in England and Wales from this cause. Most do not reach hospital alive: in 1985, 1365 deaths from carbon monoxide poisoning were reported in England and Wales whereas only 475 admissions and 10 deaths were recorded in hospitals. ${ }^{34}$ In Britain carbon monoxide is the main cause of death from poisoning in children. ${ }^{5}$ In the United States more than 3800 people are estimated to die annually from carbon monoxide poisoning, and more than 10000 people miss at least one day of work because of a sublethal exposure. ${ }^{6}$

Common sources of carbon monoxide are car exhaust fumes ${ }^{7}$ (a lethal concentration can be reached in a closed one car garage in 10 minutes $^{1}$ ); improperly maintained and ventilated heating systems ${ }^{8}$; smoke from all types of fires; and household gas (if appliances have not been converted for natural gas). Inhalation of methylene chloride (as in paint strippers) may also lead to carbon monoxide poisoning because of hepatic metabolism. ${ }^{9}$

Carbon monoxide has an affinity for haemoglobin 200-250 times that of oxygen, and the symptoms and signs that follow inhalation of carbon monoxide have been supposed to result from tissue hypoxia. Carbon monoxide combines with haemoglobin to form carboxyhaemoglobin, reducing the total capacity of the blood to carry oxygen and shifting the oxygen dissociation curve to the left. ${ }^{10}$ The binding of one or more carbon monoxide molecules to haemoglobin also induces an allosteric modification in the remaining oxygen binding sites: the affinity for oxygen of the remaining haem group is increased, and the oxygen dissociation curve is distorted as well as being shifted to the left. ${ }^{10}$ Tissue anoxia is thus far greater than would result simply from loss of oxygen carrying capacity. ${ }^{11}$ More recent experimental evidence ${ }^{12-19}$ suggests that carbon monoxide toxicity may also be due to inhibition of cellular respiration as a result of reversible binding to other haem proteins, particularly cytochrome oxidase (cytochrome a, a3), where it acts in the same way as cyanide. Although inhibition of cellular respiration has only been thought to occur in conditions of established tissue hypoxia (because the affinity of cytochrome oxidase for oxygen is much greater than that for carbon monoxide ${ }^{20}$ ), this view has recently been challenged. ${ }^{19}$

The clinical features of carbon monoxide poisoning are protean, ${ }^{21}$ and the severity of poisoning depends on the concentration of carbon monoxide in the inspired air, the length of exposure, and the general health of the exposed person..$^{22-24}$ Infants, the elderly, and patients with cardiovascular disease, anaemia, lung disease, and an increased metabolic rate are at greater risk. ${ }^{1}$ The symptoms of repeated exposure to low concentrations of carbon monoxide include headache, fatigue, difficulty in thinking, dizziness, paraesthesiae, chest pain, palpitations, visual disturbance, nausea, diarrhoea, and abdominal pain. ${ }^{25}$ Not only may performance at work and school deteriorate but also the symptoms may be mistaken for other illnesses. ${ }^{26}$ The diagnosis should thus be considered when patients present with vague and non-specific but persistent symptoms. Confirming the diagnosis analytically is often difficult as carboxyhaemoglobin concentrations (or the carbon monoxide content of exhaled air) may be low or undetectable because of the time between exposure and presentation. If there is any doubt about the relevance of individual carboxyhaemoglobin concentrations, particularly in heavy smokers, British Gas should be contacted so that gas appliances may be checked; flues and chimneys may also need to be swept. (British Gas produce an excellent video on carbon monoxide poisoning for medical and nursing audiences available from the British Gas Film and Video Library, Park Hall Road Trading Estate, London SE21 8EL.)

The features of acute carbon monoxide poisoning are better known and more easily recognised than those of chronic exposure to low concentrations. The diagnosis is 
often suggested by the circumstances in which the patient is found. The symptoms, signs, and prognosis of acute poisoning correlate poorly with the degree of carboxyhaemoglobinaemia measured on arrival at hospital. ${ }^{27}{ }^{28}$ Nevertheless, carboxyhaemoglobinaemia of less than $10 \%$ is not usually associated with symptoms, and $10-30 \%$ may cause only headache and mild exertional dyspnoea, ${ }^{24}$ though presentation with gastroenteritis should not be forgotten. ${ }^{29}$ Coma, convulsions, and cardiorespiratory arrest may occur if carboxyhaemoglobinaemia exceeds $60 \%$.

Neuropsychiatric problems may develop insidiously over weeks after recovery from carbon monoxide intoxication. ${ }^{30} 31$ These problems include intellectual deterioration, memory impairment, cerebral, cerebellar, and mid-brain damagefor example, Parkinsonism and akinetic mutism-and changes in personality typified by increased irritability, verbal aggressiveness, violence, impulsiveness, and moodiness. ${ }^{32-46}$ Up to two fifths of patients develop memory impairment, and a third suffer late deterioration of personality. ${ }^{34}$ Although there are no pathognomonic features of carbon monoxide poisoning to be found at necropsy, ${ }^{37}$ certain areas of the brain are particularly vulnerable. Bilateral necrosis of the globus pallidus is common ${ }^{38}$ and may be shown by computed tomography ${ }^{39} 40$ and magnetic resonance scanning. ${ }^{41}$ The cerebral cortex, hippocampus, and substantia nigra may also be affected. ${ }^{38}$

Patients who have been poisoned by carbon monoxide should be removed from exposure and given $100 \%$ oxygen using a tightly fitting facemask. Endotracheal intubation and mechanical ventilation may be needed if the patient is unconscious. Carboxyhaemoglobin readily dissociates when the partial pressure of carbon monoxide in the alveolar air falls below that in mixed venous blood: the elimination half life of carbon monoxide is reduced from about 250 minutes when breathing air to just under 50 minutes when $100 \%$ oxygen is given at sea level. ${ }^{42}$ Hyperbaric oxygen at 2.5 atmospheres pressure $(250 \mathrm{kPa})$ further reduces the half life to 22 minutes $^{42}$ and also increases oxygen dissolved in the blood to a concentration sufficient to meet the needs of the body even without functioning haemoglobin. ${ }^{434}$ Oxygen may also protect against inhibition of cytochrome oxidase and accelerate reactivation-as it does in experimental cyanide poisoning. 4546

Treatment with hyperbaric oxygen was first used successfully in Glasgow in the $1960 \mathrm{~s},{ }^{47}$ and subsequent clinical experience has confirmed that it can reduce morbidity (especially that due to delayed neuropsychiatric charges) from $43 \%{ }^{34}$ to less than $5 \% .{ }^{27}{ }^{35} 48$ It should be used even if patients present late in those with carboxyhaemoglobinaemia of more than $40 \%$ or a history of loss of consciousness, persistent neurological deficits (including coma), or cardiac abnormalities. ${ }^{27}{ }^{48-50}$ Unfortunately this policy has only rarely been adopted in Britain because of the few centres with suitable hyperbaric facilities. It is most important, however, that all accident and emergency and medical staff should know the location of the nearest compression chamber. (This information can be acquired urgently in Britain by contacting the duty diving medical officer on 0705822351 extension 41769 during working hours, or the duty staff officer to flag officer, Portsmouth, on extension 22008 outside working hours.)

Oxygen must be given (by whatever means) until the degree of carboxyhaemoglobinaemia is less than 5\%. General symptomatic and supportive measures may also be required. Corticosteroids, ${ }^{51}$ mannitol, ${ }^{51}$ and hyperbaric oxygen ${ }^{52}$ have all been advocated for treating cerebral oedema but are not of proved value in humans when the oedema results from carbon monoxide poisoning.

TIM MEREDITH

Senior Medical Registrar,

Guy's Hospital,

London SE1 9RT

Allister VAle

Director,

West Midlands Poisons Unit,

Dudley Road Hospital

Birmingham B18 7QH

1 Stewart RD. The effect of carbon monoxide on humans. Annual Review of Pharmacology 1975; 15:409-22.

2 Stewart RD, Baretta ED, Platte LR, et al. Carboxyhaemoglobin levels in American blood donors. FAMA 1974;229:1187-95.

3 Office of Population Censuses and Surveys. Mortality statistics 1985-cause, series DH2, table 2, ICD code 986. London: HMSO, 1987.

4 Anonymous. Hospital in-patient enquiry 1985. Main tables series MB4, tables 14 and 24, ICD code 986. London: HMSO, 1987.

Vale JA, Meredith TJ. A concise guide to the management of poisoning. 3rd ed. Edinburgh: Churchill Livingstone, 1985.

6 Anonymous. Carbon monoxide intoxication: a preventable environmental health hazard. MMWR 1982;31:529-31.

7 Baker SP, Fisher RS, Masemore WC, Sopher IM. Fatal unintentional carbon monoxide poisoning in motor vehicles. Am $\mathcal{F}$ Pub Health 1972;62:1463-7.

8 Kelly JS, Sophocleus GJ. Retinal hemorrhages in subacute carbon monoxide poisoning. Exposure in homes with blocked furnace flues. FAMA 1978;239:1515-7.

9 Stewart RD, Hake CL. Paint-remover hazard. FAMA 1976;235:398-401

10 Douglas CG, Haldane JS, Haldane JBS. The laws of combination of haemoglobin with carbon monoxide and oxygen. $\mathcal{F}$ Physiol 1912;44:275-304.

11 Roughton FJW, Darling RC. The effect of carbon monoxide on the oxyhemoglobin dissociation curve. Am f Physiol 1944;141:17-31.

12 Chance B, Erecinska $M$, Wagner M. Mitochondrial responses to carbon monoxide toxicity. Ann NY Acad Sci 1970;174:193-204.

13 Caughey WS. Carbon monoxide bonding in hemeproteins. Ann NY Acad Sci 1970;174:148-53.

14 Wald G, Allen DW. The equilibrium between cytochrome oxidase and carbon monoxide. $7 \mathrm{Gen}$ Physiol 1957;40:593-608.

15 Estabrook RW, Franklin MR, Hildebrandt AG. Factors influencing the inhibiting effect of carbon monoxide on cytochrome $\mathrm{P}_{450}$ catalyzed mixed function oxidation reactions. Ann NY Acad Sci 1970;174:218-32.

16 Penney DG, Zak R, Aschenbrenner V. Carbon monoxide inhalation: effect on heart cytochrome c in the neonatal and adult rat. $\mathcal{F}$ Tox Environ Health 1983;12:395-406.

17 Somogyi E, Sotonyi P, Balogh I, Szegedi C, Rubanyi G. New findings concerning the pathogenesis of acute carbon monoxide (Co) poisoning. Am f Forensic Med Pathol 1981;2:31-9.

18 Goldbaum R, Ramirez RG, Absalon KB. What is the mechanism of carbon monoxide toxicity? Aviat Space Environ Med 1975;46:1289-91.

19 Piantadosi CA. Carbon monoxide, oxygen transport, and oxygen metabolism. $\mathcal{f}$ Hyperbaric Med 1987;2:27-44.

20 Ball EG, Strittmatter CF, Cooper O. The reaction of cytochrome oxidase with carbon monoxide f Biol Chem 1951;193:635-47.

21 Meredith TJ, Vale JA, Proudfoot AT. Poisoning caused by inhalation agents. In: Weatherall DJ, Ledingham JGG, Warrell D, eds. Oxford textbook of medicine. 2nd ed. Oxford: Oxford University Press, 1987;6:53-9.

22 Coburn RF, Forster RE, Kane PB. Considerations of the physiological variables that determine the blood carboxyhemoglobin concentration in man. F Clin Invest 1965;44:1899-910.

23 Stewart RD, Peterson JE, Baretta ED, Bachand RT, Hosko MJ, Herrmann AA. Experimental human exposure to carbon monoxide. Arch Environ Health 1970;21:154-64.

24 Burney RE, Wu S-C, Nemiroff MJ. Mass carbon monoxide poisoning: clinical effects and results of treatment in 184 victims. Ann Emerg Med 1982;11:394-9.

25 Kirkpatrick JN. Occult carbon monoxide poisoning. West $\mathcal{f}$ Med 1987;146:52-6.

26 Grace TW, Platt FW. Subacute carbon monoxide poisoning. Another great imitator. FAMA 1981;246:1698-700.

27 Norkool DM, Kirkpatrick JN. Treatment of acute carbon monoxide poisoning with hyperbaric oxygen: a review of 115 cases. Ann Emerg Med 1985;14:1168-71.

28 Sokal JA, Kralkowska E. The relationship between exposure duration, carboxyhaemogloblin, blood glucose, pyruvate and lactate and the severity of intoxication in 39 cases of acute carbon monoxide poisoning in man. Arch Toxicol 1985;57:196-9.

29 Gemelli F, Cattani R. Carbon monoxide poisoning in childhood. Br Med f 1985;291:1197.

30 Ginsberg MD. Delayed neurological deterioration following hypoxia. Adv Neurol 1979;26:21-44.

31 Choi HS. Delayed neurologic sequelae in carbon monoxide intoxication. Arch Neurol 1983;40: 433-5.

32 Gilbert GJ, Glaser GH. Neurologic manifestations of chronic carbon monoxide poisoning. $N$ Engl f Med 1959;264:1217-220.

33 Garland $\mathrm{H}$, Pearce J. Neurological complications of carbon monoxide poisoning. $Q \mathcal{F} \mathrm{Med}$ 1967;36:445-55.

34 Smith JS, Brandon S. Morbidity from acute carbon monoxide poisoning at three-year follow-up. BrMed f 1973;i:318-21.

35 Myers RAM, Snyder SK, Emhoff TA. Subacute sequelae of carbon monoxide poisoning. Ann Emerg Med 1985;14:1163-7.

36 Werner B, Back W, Akerblom H, Barr PO. Two cases of acute carbon monoxide poisoning with delayed neurological sequelae after a "free" interval. $\mathcal{J}$ Toxicol Clin Toxicol 1985;23:249-65.

37 Finck PA. Exposure to carbon monoxide: review of the literature and 567 autopsies. Milit Med 1966;131:1513-9.

38 Lapresle J, Fardeau M. The central nervous system and carbon monoxide poisoning II. Anatomical study of brain lesions following intoxication with carbon monoxide (22 cases). Prog Brain Res 1967;24:31-74.

39 Sawada Y, Sakamoto T, Nishide K, et al. Correlation of pathological findings with computed tomographic findings after acute carbon monoxide poisoning. N Engl f Med 1983;308:1296.

40 Sawada Y, Ohashi N, Maemura K, et al. Computerized tomography as an indication of long-term outcome after acute carbon monoxide poisoning. Lancet 1980; i:783-4.

11 Horowitz AL, Kaplan R, Sarpel G. Carbon monoxide toxicity: MR imaging in the brain. Radiology 1987;162:787-8.

42 Pace N, Strajman E, Walker EL. Acceleration of carbon monoxide elimination in man by high pressure oxygen. Science 1950;111:652-4. 
43 Norman JN, Ledingham IMcA. Carbon monoxide poisoning: investigations and treatment. Prog Brain Res 1967;24:101-22.

44 Sluijter ME. The treatment of carbon monoxide poisoning by administration of oxygen at high atmospheric pressure. Prog Brain Res 1967;24:123-82.

45 Takano T, Miyazaki Y, Nashimoto I, Kobayashi K. Effect of hyperbaric oxygen on cyanide intoxication: in situ changes in intracellular oxidation reduction. Undersea Biomed Res intoxication:

46 Isom GE, Way JL. Effects of oxygen on the antagonism of cyanide intoxication: cytochrome oxidase, in vitro. Toxicol Appl Pharmacol 1984;74:57-62.

47 Smith G, Sharp GR. Treatment of carbon monoxide poisoning with oxygen under pressure. Lancet 1960;ii:905-6.

48 Mathieu D, Nolf $M$, Durocher A, et al. Acute carbon monoxide poisoning. Risk of late sequela and treatment by hyperbaric oxygen. $\mathcal{J}$ Toxicol Clin Toxicol 1985;23:315-24.

49 Myers RAM, Linberg SE, Cowley RA. Carbon monoxide poisoning: the injury and its treatment. fournal of the American College of Emergency Physicians 1979;8:479-84.

50 Klindwall EP. Hyperbaric treatment of carbon monoxide poisoning. Ann Emerg Med 1985;14: 1233-4.

51 Fishman RA. Brain edema. N Engl f Med 1975;293:706-11.

52 Sukoff $M H$, Ragatz RE. Hyperbaric oxygenation for the treatment of acute cerebral edema. Neurosurgery 1982;10:29-37.

\section{Psychiatry: private and public provision}

Conditions seem favourable for further expansion in private acute psychiatric care. The government is encouraging managers of district and regional health authorities to seek closer cooperation between the National Health Service and private providers, and the generally low standard of NHS provision is undoubtedly an incentive for those who can afford it to seek private treatment. Counselling for people with psychiatric problems is already highly commercialised. Three questions arise from the expansion in private psychiatry: What is happening in the private psychiatric sector? What effects are current resource constraints having on NHS psychiatry? What form of coexistence between private and public provision will prove most effective and efficient?

The market in private acute psychiatric treatment is still small, ${ }^{1}$ largely because people with mental illness descend down the social scale. In addition, insurance risks are high, and until recently private treatment was provided mainly in a few hospitals remote from most of the population. At the same time, private practice among NHS consultants has remained undeveloped, focusing mainly on the outpatient treatment of patients with neuroses.

Now the number of consultant psychiatrists working in the private sector and the number of private hospitals are increasing, predominantly in the more affluent south. Unlike in the NHS, morale is high and the facilities are usually impressive. In 1980 there were 25 full time private psychiatrists in England and Wales; by 1986 there were 60. In addition, 300 consultants had by 1986 developed a substantial commitment to private practice. ${ }^{2}$ There are over 20 private psychiatric hospitals with almost 2000 beds $(10 \%$ occupied by chronically ill patients). ${ }^{2}$ In all, about $4 \%$ of beds for patients with acute mental illness are private (compared with about $10 \%$ of beds for elective surgery). ${ }^{1}$

Commercial and financial information on private medicine is difficult to obtain, ${ }^{34}$ but it has been estimated that in 1984 private acute psychiatry was generating a return of around $£ 25 \mathrm{~m}$ annually (compared with about $£ 500 \mathrm{~m}$ for acute general hospital care). ${ }^{1}$ Since the early 1980 s the domination of this market by British charitable institutions has been increasingly challenged, particularly by a few American multinational companies, which are now responsible for about half the total cash turnover. ${ }^{3}$ Their investment and the resulting competition has affected the pattern of provision. For example, consultant private practice has moved away from the conventional "closed" model of psychiatric inpatient care, with treatment being provided entirely by full time hospital staff, to an "open" model in which local consultants have admitting rights.

How resource constraints are affecting NHS psychiatry is uncertain and likely to remain so-mainly because the necessity for, and sufficiency of, psychiatric treatment is hard to quantify. Furthermore, ideological differences among both providers and consumers lead to contradictory judgments, ${ }^{5}$ as can be illustrated by events at the Bethlem Royal Hospital and the Maudsley Hospital and at the Institute of Psychiatry. Last year a group of doctors and academics wrote to The Times: "The government's conjoint undermining both of the universities and the NHS constitutes an immensely threatening pincer movement on this centre [and] is a devastating attack on the core of British psychiatry and on the future care of a vulnerable sector of the community. Our financial crisis has meant that of the last eight academic posts to fall vacant at the Institute, only one could be filled, and three university chairs have been lost. The Bethlem/Maudsley are at the same time faced with a $£ 400000$ per year deficit which will require drastic cuts in patient services." This year the chairman of the Joint Hospital Special Health Authority replied to subsequent similar criticism": "The financial crisis is not the same and the deficit has been reduced from $£ 1.4$ million to $£ 367000$. Cuts are not inevitable and are indeed not foreseen." ${ }^{8} \mathrm{He}$ added that since 1979 the joint hospital had opened four new units at a total revenue increase of $£ 3.3 \mathrm{~m}$; in addition, a new unit for computed tomography opened last year, and building has started on a first block of new wards (at a capital cost of $£ 3 \cdot 7 \mathrm{~m}$ ).

The eventual mix between private and public mental health care will be resolved by market forces and empirical means. Meanwhile, a key NHS objective continues to be to provide cost effective treatments that are flexible and responsive to changing circumstances. Psychiatric treatment is heterogeneous, and the therapeutic value of most of its components has not been proved. The NHS thus cannot hope to provide all specialist psychiatric services, and Professor Sydney Brandon asked in his recent report on a "subversive foray into private practice": "Do we have to recognise that certain kinds of care such as some or all of secure accommodation, the management of the severely head injured, psychosexual counselling, intensive psychotherapy or long term social skills training cannot be provided as basic care and have to be contracted out or sought privately?"'

Senior Lecturer,

GREG WILKINSON

General Practice Research Unit,

Institute of Psychiatry,

London SE5 8AF

1 Laing W. Private health care. Studies of current health problems No. 79. London: Office of Health Economics, 1985

Brandon S. Conference report: a subversive foray into private practice. Bulletin of the Royal College of Psychiatrists 1987;11:23-4.

Fitzhugh $W$. The Fitzhugh directory of independent hospitals' and provident assaciations' financial information. London: Healthcare Information Services, 1986.

Grant C. Private health care in the UK: a review. Special report No. 207. London: The Economist Intelligence Unit, 1985.

5 McLachlan G, Maynard A. The public/private mix in health care. The emerging lessons. In McLachlan G, Maynard A, eds. The public/private mix for health. The relevance and effects of change. London: Nuffield Provincial Hospitals Trust, 1982.

6 Edwards G, Gunn G, Gray G, et al. Fears for leading psychiatric centre. The Times 1986 May 27:13 (col 4-5).

7 Lewis G, Appleby L. Doubts about keeping NHS safe. The Times 1987 May 22:17 (col 4)

8 Clout IR. Maudsley measures. The Times 1987 May 29:13 (col 4-5). 